\title{
Vulvodynia Treated by Sacral Nerve Stimulation: Case Report
}

\author{
Mai A. Banakhar, MBChB, SSC-Urol
}

Assistant Professor, Consultant Urology, Department of Urology, Faculty of Medicine

King Abdulaziz University, Jeddah, Saudi Arabia

\section{Correspondence}

Dr. Mai A. Banakhar

P.O. Box 80216, Jeddah 21589, Saudi Arabia

e.M: mbanakher@kau.edu.sa

Submission: 05 Sep. 2016

Accepted: 25 Sep. 2016

\section{Citation}

Banakhar MA. Vulvodynia treated by sacral nerve stimulation: Case report . JKAU Med Sci 2016; 23 (4): 49-51. DOI: 10.4197/Med. 23.4 .6

\begin{abstract}
Sacral nerve stimulation is an FDA approved therapy for refractory overactive bladder, frequency urgency syndrome and nonobstructive urinary retention. It has been applied to other off label uses such as interstitial cystitis and chronic prostatitis for subjective patient symptomatic improvement. We report a 54 year old female who presented with vulvodynia and had been treated successfully with sacral neuromodulation.
\end{abstract}

\section{Keywords \\ Vulvodynia; Sacral nerve stimulation; Treatment; Sacral neuromodulation; Pelvic pain syndrome}

\section{Introduction}

hronic pelvic pain (CPP) is a disabling syndrome associated with neuropathic syndromes. So far it is associated with vulvodynia, interstitial cystitis, and chronic prostatitis. Vulvodynia is a chronic genital pain in women. It is a not uncommon condition despite being reported infrequently in the literature. This condition is usually treated by pain medications, topical hormones or anesthesia, pelvic floor therapy and nerve blocks. We report a case treated successfully using sacral neuromodulation.

\section{Case Report}

A middle age female (54 years old) presented to clinic with vulvar pain continuous without touching for the last 9 months. The pain was more toward the left vulva and associated with severe pain resulting in avoidance of sexual activity for the last 6 months. Her other systems review were not significant, with no previous medical nor surgical history. Local examination showed normal pink vagina, no discharge or ulcers, no fibrosis with painful examination without identifiable pathology. Her pain score on visual analog scale (VAS) was 9. She received multiple pain medications, topical hormones and pelvic rehabilitation sessions, but without any clinical benefit. The patient was referred to gynecologist who excluded local causes of her complaint and a psychiatric clinic which confirmed normal mental health. Patient was counseled for sacral neuromodulation therapy and staged implantation. Stage one test trial was done under general anesthesia and fluoroscopic localization of the third sacral foramen. Bilateral stimulation of third sacral root elicited bellows contractions without any foot movement at amplitude of six volts. We selected the left third sacral root for tined lead insertion for her symptom lateralization to the left side. Electrode was tunneled to the right side gluteal pocket and delivered to the contralateral side after fixing it to connection. Patient spent two weeks before the second stage procedure for implantation of internal pulse generator (IPG), at which her pain scale decreased from 9 to 1 , at that time patient was instructed to postpone sexual activity for six months to prevent electrode migration. Patient had her IPG device implanted successfully with programming. At her follow up after four months she was doing fine with the device and her VAS was still 1 and she was able to resume sexual activity. 


\section{Discussion}

Sacral nerves carry both parasympathetic and somatic stimulation to bladder detrusor, urethra, and pelvic floor. These stimulations are under higher center control. Sacral neuromodulation (SNM) works by modulating impulses running in sacral nerves by electrical stimulation through tined lead inserted into third sacral foramen. It has been FDA approved in refractory overactive bladder, frequency urgency syndrome and non-obstructive urinary retention ${ }^{[1-7]}$. Other off label uses including pelvic pain syndrome, interstitial cystitis ${ }^{[8,9]}$ and fecal incontinence are showing clinical management role. Pauls et al., ${ }^{[10]}$ reported an SNM effect on female sexual function mainly desire, lubrication, orgasm, satisfaction, and pain. Banakhar et al., ${ }^{[1]]}$ reported desire and orgasm improvement. While other studies showed improvement in all six domains of female sexual function index ${ }^{[12]}$.

So far two cases have reported SNM therapy for vulvodynia (nerve entrapment postoperative hysterectomy while the other case as a part of pelvic pain syndrome $)^{[13]}$. Vulvodynia is unusual indication for SNM. We think that neuromodulation will play a major role in the future in treating all nerve related pelvic pain.

\section{Conclusion}

Sacral neuromodulation may play a role in future treatment of vulvodynia patients not responding to conservative measures.

\section{Conflict of Interest}

The author has no conflict of interest.

\section{Disclosure}

The author did not receive any type of commercial support either in forms of compensation or financial for this study. The author has no financial interest in any of the products or devices, or drugs mentioned in this article.

\section{Ethical Approval}

Signed consent from patient to report her case.

\section{References}

[1] Abrams P, Andersson KE, Birder L, Brubaker L, Cardozo L, Chapple C, Cottenden A, Davila W, de Ridder D, Dmochowshi R, Drake M, Du Beau C, Fry C, Hanno P, Hay
Smith J, Heerschorn, S, Hosker G, Kelleher C, Koelbl H, Khoury S, Madoff R, Milsom I, Moore K, Newman D, Nitti V, Norton C, Nygaard I, Payne C, Smith S, Staskin D, Tekgul S, Thuroff J, Tubaro A, Vodusek DB, Wein A, Wyndaele JJ; Member of the Committees. 4th International Consultation on Incontinence. Recommendations of the International Scientific Committee: Evaluation and treatment of urinary incontinence, pelvic organ and fecal incontinence. 4th ed. Paris, France: Health Pub Ltd., 2009. 1767-

[2] Shaker HS, Hassouna MM. Sacral root neuromodulation in idiopathic nonobstructive chronic urinary retention. J Urol 1998; 159(5): 1476-1478.

[3] Al-Shaiji TF, Banakhar M, Hassouna MM. Pelvic electrical neuromodulation for the treatment of overactive bladder symptoms. Adv Urol 2011; 2011: 757454.

[4] Banakhar MA, Al-Shaiji TF, Hassouna MM. Sacral neuromodulation and refractory overactive bladder: an emerging tool for an old problem. Ther Adv Urol 2012; 4(4): 179-185.

[5] Kruse MN, de Groat WC. Spinal pathways mediate coordinated bladder/urethral sphincter activity during reflex micturation in decerebrate and spinalized neonatal rats. Neurosci Lett 1993; 152(1-2): 141-144.

[6] Elkelini MS, Abuzqaya A, Hassouna MM. Mechanisms of action of sacral neuromodulation. Int Urogynecol J 2010; 21 Suppl 2: S439-S446.

[7] Bernstein AJ, Peters KM. Expanding indications for neuromodulation. Urol Clin North Am 2005; 32(1): 59-63.

[8] Banakhar MA, Al-Shaiji TF, Hassouna MM. Sacral neuromodulation in the treatment of interstitial cystitis/ painful bladder syndrome: Should it be off label? Curr Bladder Dysfunct Rep 2012; 7: 120-124.

[9] Al-Zahrani AA, El Zayat EA, Gajewski JB. Long-term outcome and surgical interventions after sacral neuromodulation implant for lower urinary tract symptoms: 14 years experience at 1 center. J Urol 2001; 185: 981-986.

[10] Pauls RN, Marinkovic SP, Silva WA, Rooney CM, Kleeman SD, Karram MM. Effects of sacral neuromodulation on female sexual function. Int Urogynecol J Pelvic Floor Dysfunct 2007; 18(4): 391-395.

[11] Banakhar MA, Gazwani Y, El Kelini M, Al-Shaiji TF, Hassouna MM. Effect of sacral neuromodulation on female sexual function and quality of life: Are they correlated? Can Urol Assoc J 2014; 8(11-12): e762-e767.

[12] Signorello D, Seitz CC, Berner L, Trenti E, Martini T, Galantini A, Lusurdi L, Lodde M, Pycha A. Impact of sacral neuromodulation on female sexual function and his correlation with clinical outcome and quality of life indexes: A monocentric experience. J Sex Med 2011; 8(4): 1147-1155.

[13] Zahibi N, Mourtzinos A, Maher MG, Raz S, Rodríquez LV. The effects of bilateral caudal epidural S2-4 neuromodulation on female sexual function. Int Urogynecol J 2008; 19: 697700. 


\section{علاج الم القرج المزمن عند النساء باستخدام اجهزه تحفيز اعصاب الحوض: ثمزير حاله}

$$
\begin{aligned}
& \text { قسم جراحه احلخلى والمسالك البولية، كلبه الطب، جامعه الملك عبد العزيز } \\
& \text { جلة ـ المدلكة العربية السعودية السية }
\end{aligned}
$$

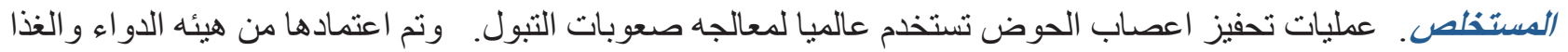

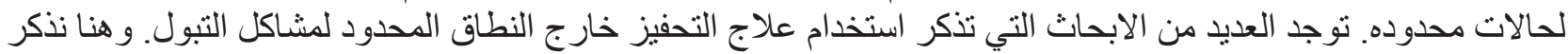

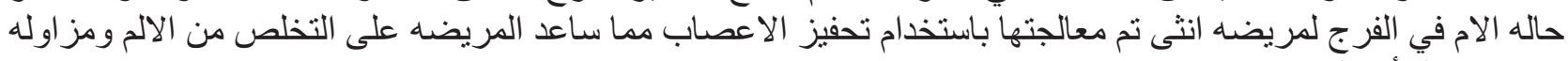
حياتها بشكل أفضل. 